\title{
The 0 bservatory of the Américas as a network in environmental and worker health in the Americas
}

\author{
O Observatório das Américas \\ como rede de saúde ambiental e \\ do trabalhador nas Américas
}

Carlos Eduardo Siqueira 1

Fernando Carvalho 2

\footnotetext{
1 Department of Work Environment, University of $M$ assachusetts Lowell, One University Avenue, Lowell, M A 01854 USA. carlos siqueira@uml.edu 2 Departamento de M edicina Preventiva, UFBA.
}

Abstract This article revi ews the scope of several Observatories found by a search in the Internet through the Google search engine. After examining these observatories, it describes the aims and initial accomplishments of the $O$ bservatory of the A mericas as a network of professionals and activists from different countries in the A mericas. The article concludes with a discussion of the pattern identified among these observatories: they may be clearinghouses or networks, or both.

Key words Observatory, N etwork, Environmental and worker health
Resumo Este artigo descreve o objetivo de vários observatórios en contrados pela busca na Internet, no motor de busca Google. D epois de examinar esses observatórios, 0 artigo descreve os objetivos e realizações iniciais do 0 bservatório das A méricas como rede de profissionais e ativistas de diferentes países das A méricas. 0 artigo conclui discutindo o padrão identificado entre esses observatórios como centros de informação ou redes, ou ambos.

Palavras-chave O bservatório, Rede, Saúde ambiental e do trabalhador 


\section{Introduction}

According to the Random H ouse Dictionary (1967), an observatory is: 1. a place or building equipped and used for making observations of astronomical, meteorological, or other natural phenomena, esp. a place equipped with a powerful telescope for observing the planets and stars; 2 . an institution which controls or carries on the work of such a place; 3 . a place or structure for affording an extensive view; outlook.

W hile the word observatory has always been linked to the science of Astronomy, researchers and social institutions all over the world have used the third definition above to name initiatives aimed at studying a variety of social phenomena. Networks of labor unions, community organizations, multilateral and government agencies, and universities have been formed over the last decade to describe and analyze the impact of national and international economic policies on the health of populations, changes in the world of work caused by globalization of neoliberal policies or human resources development in healthcare in the Americas.

$M$ aybe the proliferation of a broad range of research activities developed by observatories is related to the growing worldwide awareness that one can only understand reality "thinking globally and acting locally." Furthermore, the economic, social, political, scientific, technological, and cultural trends that started within the last decades of the twentieth century seem to have consolidated a new paradigm that demands and makes easier the creation of international networks for understanding and changing reality. In this paper we first review the scope of several observatories found by a search in the Internet through the Google search engine <http://www. google.com>. N ext we summarize the aims and initial accomplishments of the Observatory of the Americas. Last we discuss the pattern identified in observatories described, emphasizing to what extent they have characteristics of networks or are organized to observe social phenomena.

\section{O bservatory of $\mathrm{H}$ ealth}

The O bservatório da Saúde - <http://www. opas.org.br/observatorio/observatorios.cfm \#>
- is part of a cooperation between state health departments in Brazil and the PanAmerican $\mathrm{H}$ ealth Organization (PAHO). This Observatory is a website that uses existing health information, analyzes it, and makes it available to anyone interested in monitoring, studying, or deepening the knowledge of a given health subject. Information produced by the O bservatório da Saúde should be used by managers, health professionals and members of national, state, and local $\mathrm{H}$ ealth Councils. Universities, the press, and average citizens interested in in health topics can also benefit from these analyses. The World Health Organization (WHO/ PAH O) Decentralized Technical Cooperation has al so stimulated Brazilian states to implement their own state observatories.

The O bservatório da Saúde is composed of two smaller observatories:

a) Observatório da Regionalização ( O bservatory of Regionalization) <http://www.opas .org. br/ observatorio/principal.cfm?hobsnumcod $=12>$. This O bservatory is part of the PAHO technical cooperation program with Brazil and aims at monitoring the federal government policies of decentralization and regionalization of the Brazilian Unified $\mathrm{H}$ ealth System (SUS). It also aims at contributing to solving problems in the health system together with health managers who wish to improve the quality and equity of health services in Brazil.

b) Observatório da Reforma (O bservatory of the Health System Reform) <http://www. opas.org.br/observatorio/observatorios.cfm\# $>$. This Observatory aims at strengthening the partnership between PAH O's Technical Cooperation program and Brazilian states by stimulating the creation of permanent "watchdog" groups. These groups would monitor the ongoing health system reform and flag rel evant issues that may arise during its implementation. The O bservatório da Reforma intends to follow up and understand the changing political conjunctures in each state by observing the particularities of each state. It proposes to establish joint actions with state Health Departments and local communities.

\section{Trade Union Technical Bureau (TUTB) Observatory}


The European Trade U nion Technical Bureau for $\mathrm{H}$ ealth and Safety was established in 1989 by the European Trade U nion Confederation (ETUC) in order to monitor the drafting, transposition, and application of European working environment legislation. The TUTB coordinates the work carried out by the Workers' Group of the Advisory Committee for Safety, $\mathrm{H}$ ygiene, and $\mathrm{H}$ ealth Protection at Work, which forms the basis of its opinions to the European Commission on proposed new European Union H ealth and Safety at W ork D irectives. The TUTB set up an Observatory (website) - <http://www.etuc.org/ tutb/uk/projetsl. html> - to follow up the implementation of health and safety legislation in the countries that are members of the European U nion. The TUTB Observatory has focused on several directives: the Framework Directive, the $M$ aternity Protection, Work with Display Screen Equipment, and $M$ anual $\mathrm{H}$ andling of Loads Directives. These are the first Directives that require the member states to draw up national reports on their implementation. The Observatory of the TUTB has published articles and other publications that analyze the implementation of the Directives.

\section{Social O bservatory of Latin America}

The O bservatório Social da A mérica Latina (OSAL) <http://osal.clacso.org/espanol/html/ primera.html > - is run by the Consejo Latinoamericano de Ciencias Sociales (CLACSO) since February 2000 . Its objective is to present information that allows for a critical, historical-structural debate about the new realities faced by Latin American societies. It focuses especially on the implementation of neoliberal policies in the last decades. The OSAL aims at stimulating analysis and discussion about the numerous forms of social antagonism found in these societies and the characteristics of social movements in the region. This Observatory is also taken as a virtual space for exchanges among social researchers and political and social movements. The OSAL has published a periodical since $M$ ay 2000 , which is distributed in the Americas, targeting researchers, politicians, and social leaders.

\section{Social O bservatory}

Based in Argentina, the Social Observatory <http://www.observatoriosocial.com.ar/>- is addressed to intelectuals and policy makers, particularly politicians and their technical staff. The main objective of this O bservatory (website) is to develop and discuss concepts that could help decision-makers accomplish their political tasks. The Observatório Social intends to gather, process, and disseminate, in a pluralistic way, information that discusses the several domains that represent the Social. This O bservatory has worked along the following lines: indicators for understanding social dynamics, prevention of addiction, education for social development, housing and urban poverty, links between economic and social policy, and the social economy. This Observatory plans to set up a network of similar observatories of institutions and community centers all over Argentina, not only through the Internet or other media but also through relationships that connect and commit people and institutions to each other. The Observatório Social publishes a periodical to publicize their ideas and actions.

\section{O bservatory of Work in Globalization}

The $\mathrm{O}$ bservatory of Work in Globalization <http://www.observatoriodeltrabajo.org/> - is a joint initiative of the Fundación Paz y Solidaridad Serafín Aliaga of the Comissiones O breras de Espanha and the Agencia de Cooperación Internacional, M inisterio de A suntos Exteriores of Spain. Created in 2002, it has 350 subscribers and more than 15,000 visits to their home page. This O bservatory has a strong focus on the globalization process. The Observatorio del Trabajo seems to be very politically active, according to their motto: "To observe and to act". It has organized and/or participated in several workers' events against globalization at the local and international levels, such as the 2002 World Social held at Porto Alegre, Brazil.

\section{Social Watch}

The Social W atch - <http://www.observato- 
riosocial.org.br> - is an initiative of the Brazilian Central Ú nica dos Trabalhadores (CUT), the largest national trade union organization in Brazil, in collaboration with the Centro de Estudos de Cultura Contemporânea (CEDEC), the Departamento Intersindical de Estudos Socioeconômicos (DIEESE), and the Rede Inter-U niversitária de Estudos e Pesquisas sobre o Trabalho (UNITRABALH O). It has international support of institutions from Finland, Holland, N orway, the U.S., Germany, the International Labor Office (ILO), and the Public Services International (PSI).

This O bservatory aims at monitoring fundamental labor rights practices of national (public and private) and multinational companies in Brazil. The research methodology adopted by the Observatório Social starts with gathering available information (from other websites or the press) on selected businesses regarding issues such as stock ownership and control, historical facts, environmental and worker complaints, etc. N ext, interviews are conducted with workers, labor union representatives, and business managers to document potential violation of labor rights. The information collected is then analyzed taking into consideration language of I LO Conventions, Social Charters, Voluntary Codes of Conduct of Businesses, the Organization of Economic Cooperation and $\mathrm{De}$ velopment (OECD) Directives about M ultinational Companies, the United $\mathrm{Nations}$ Global Compact, and other company behavior standards advocated by International Professional Secretariats (IPS) and the International Confederation of Free Trade U nions (ICFTU).

One of the most important projects of the Social Watch is the Business M onitoring Project that aims at globalizing the fight for labor rights. This innovative approach is promoted by the Dutch $\mathrm{N}$ ational Confederation of Workers (FNV) as a new strategy to deal with multinational companies. Unilever, Philips, Ahold (chain of supermarkets called Bompreço in Brazil) and Akzo Nobel are Dutch enterprises that run production units in South Africa, Brazil, South Korea, Poland, $M$ exico, and the Czech Republic. Studies on the performance of these four multinationals were carried out in all these countries. In Brazil, the O bservatório Social has al ready researched Ahold, Unilever, and Akzo Nobel.
The Philips study is under development. The O bservatory also disseminates studies performed in other countries.

\section{Observatory of the Americas}

The Observatory of the Americas is envisioned as a loose network of professionals and activists in occupational and environmental health in the Americas. It would serve as a tool for international cooperation and solidarity among the different institutions and efforts taking place in the Americas to improve worker and community health. The sharing of experiences and knowledge among people and institutions interested in work environment issues is the common bond that would energize this network (Siqueira 2002).

Two conferences were held on August 2000 in Morelia, M exico; and June 2002 in Salvador, Brazil to bring together representatives from academia, N GOs, labor unions, as well as public policy makers, from South, Central, and North America to exchange information and views about worker and community health in the region of the A mericas. Participants in both conferences discussed the emergence and implementation of neoliberal economic policies in Latin A merica and its negative impacts on the world of work, with particular emphasis on the health and safety of workers. Presentations about the N orth American FreeTradeAgreement (NAF$T A$ ), the Free Trade Area of the Americas FTAA), and Globalization and $H$ ealth, framed the overall political agenda of the O bservatory as anti-neoliberal.

The development of this network of progressive health and safety and environmental professionals, activists, and academics in the Americas was considered an important mechanism for them to resist and counteract the "free trade" policies proposed by theU.S. government and its allies in the A mericas.

$M$ embers of the network have been involved in the following activities:

a) Development and implementation of a five-year project funded by the U.S. John Fogarty Institute of the $\mathrm{N}$ ational Institutes of $\mathrm{H}$ ealth to promote technical cooperation in human resource development in occupational and environmental health. The W ork and $\mathrm{H}$ ealth in Brazil and M exico project is a partnership between the U niversity of $M$ assachu- 
setts Lowell, the U niversity of Sonora (M exi$\mathrm{CO})$, the Federal U niversities of Pelotas and Bahia, and the University of Campinas (Brazil). The project aims at training M exican and Brazilian occupational and environmental health professionals at the graduate level in the Department of Work Environment of U M ass Lowell, conducting joint research with professionals from Brazil and M exico, and implementing short-term courses in subject areas deemed important.

b) Organization of a series of health and safety and environmental workshops during the Third W orld Social Forum held in 2003 in Porto Alegre, Brazil. The few hundred Brazilian professionals and activists who attended the workshops decided to establish "a network of networks" of occupational and environmental groups that are involved in worker and environmental health issues such as chemical pollution, sustainable housing, ban of asbestos, and water and sanitation.

c) Production of a special issue of the Brazilian journal Ciência e Saúde Coletiva, published by the Brazilian Association of Collective $\mathrm{H}$ eal th (ABRASCO), to discuss themes addressed by the 2002 Conference in Bahia.

d) Short-term visits by network members from Brazil, U.S., and M exico to each other's institutions to discuss joint publications, address environmental and occupational health problems, and plan for future initiatives. In addition, virtual communication between and among people who participated in the Conferences has increased significantly, allowing for fast dissemination of information and exchange of ideas.

The Observatory of the Americas is a "network in progress" that faces many obstacles but also has good potential to becomea fully developed and successful international network. On the one hand it has not yet been able to establish a formal organizational structure composed of a group of institutional hosts that could, for example, create a website for it. The informal and virtual ties between individual and institutional members has so far made it difficult for individuals to join it and commit to the goals and actions of the network, and for international organizations and funding agencies to support it. Yet, this informality has also enabled the network to remain flexible and open to new ideas and paths for growth by linking with more consolidated national and international net- works and organizations. Since this O bservatory is only three years old, it is still early to tell whether this network will evolve as a chain network, a star of hub network or an all-channel network model, as proposed by Arquilla and Ronfeldt (2001).

\section{Discussion}

The observatories described in this article are but a sample of the growing number of initiatives by non-governmental, multilateral, and governmental organizations that unequivocally call themselves as such. A closer look at these observatories seem to indicate that there are two major, though not opposite, types: a) the observatory as a clearinghouse and $b$ ) the observatory as a network.

Observatories that are organized as a virtual clearinghouse or websites ai $m$ at following up the broad impact of social policies in a given geographical boundary, that range from a continent (Europe for the TUTB Observatory) to the whole world (Social Watch). All but one of observatories mentioned in this article fit this approach. The term observatory is thus very appropriate to summarize the major activities conducted by them. The collection, analysis, and dissemination of information revolve around observing time trends, statistical patterns, and geographic contrasts between and among regions, countries, and social groups.

Observatories that are organized as a network of people who share political agendas and goals, aim at coordinating their actions toward changing economic, social, technological and other policies at the national, regional and international levels. Although information collection and dissemination is al so important in this type, they are not mainly organized to observe trends, patterns, or contrasts. Rather, the network is seen as an organizing tool for people to work together to change societies in a given direction. The word "observatory" is probably not be the best descriptor for such activities. The word "forum," as used in the World Social Forum held in Porto Alegre, may be a better name for it. Actually, W hitaker argued that the W orld Social Forum is a space for people to share experiences and ideas to create another world (W hitaker 2001). "Another world is possible" has become the slogan that attracted thou- 
sands of people to participate in the three fora held in the last three years in Brazil.

The Social Watch seems to fit this description as it operates as an international network that monitors labor rights violations to change illegal and unethical business behaviors. The O bsevatory of W ork also has similar characteristics. The Observatory of the A mericas certainly matches the profile of a network.

Whatever the specific forms or objectives of the observatories examined above, there seems to be a centuries- old metaphor underlying all of them: in order to understand the complexities of the world, one needs to ob- serve it together with fellow human beings. If this idea was true in the M iddle-Age regarding the natural world, when the first observatories were created to observe and discover the $U$ niverse, it is now essential. By the year 2003 , it is fairly clear to all that we do live in a global village that requires multiple connections and links for us to make sense of it.

The Observatory of the Americas may thus be viewed as a strategic effort to build international connections and linkages that enable a better understanding of the nature of the environmental and occupational health problems in the Americas and how to changethem. All aboard!!!

\section{Bibliographic references}

ArquillaJ \& Ronfeldt D 2001. N etworks and N etwars. The Future of Terror, Crime and M ilitancy. Rand Corporation. California.

Random House Dictionary of the English Language 1967. Random H ouse. N ew York.

Siqueira CE, Levenstein C \& DeLaurier G 2002. Report from M orelia: Toward the Formation of the 'O bservatory of the Americas'. N ew Solutions, a J ournal of Environmental and 0 ccupational $\mathrm{H}$ ealth Policy 12 (1):79-84

Whitaker F 2001. Lessons from Porto A legre. Available at http://www.forumsocialmundial.org.br/DINAM IC/ eng_balanco_ChicoW.asp

Artigo apresentado em 4/9/2003

Aprovado em 10/10/2003

Versão final apresentada em 8/11/2003 